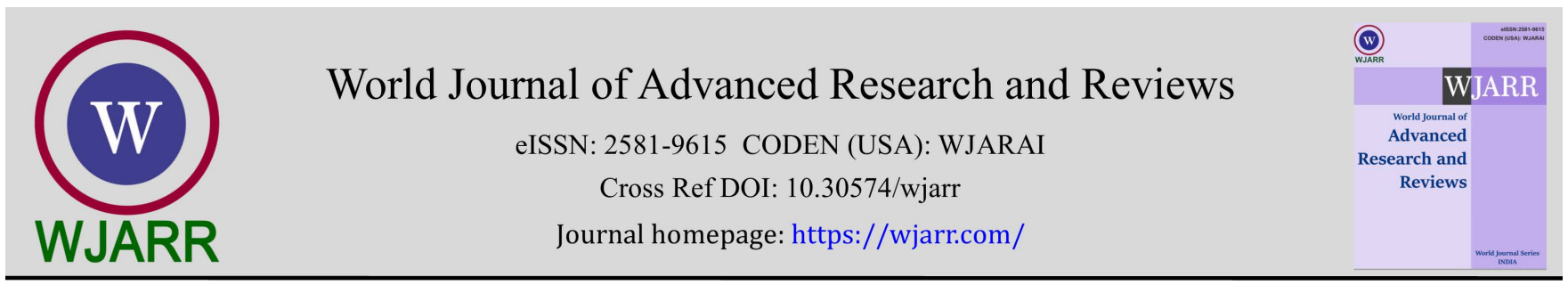

(RESEARCH ARTICLE)

\title{
Thermal, physical, and engineering properties of Okra (Abelmoschus esculentus L. (Moench) grown in Nigeria
}

\author{
Abdulkareem Adamu Obomeghei ${ }^{1, *}$, Amina Osizemeyele Yusuf ${ }^{2}$ and Bello Andrew Ojutomori ${ }^{3}$ \\ ${ }^{1}$ Department of Food Technology, University of Ibadan, Ibadan, Oyo State, Nigeria. \\ 2 Department of Food Technology, Auchi Polytechnic, Auchi. Edo State, Nigeria. \\ ${ }^{3}$ Department of Statistics, Auchi Polytechnic, Auchi, Edo State. Nigeria.
}

World Journal of Advanced Research and Reviews, 2022, 13(02), 153-162

Publication history: Received on 16 August 2021; revised on 06 February 2022; accepted on 08 February 2022

Article DOI: https://doi.org/10.30574/wjarr.2022.13.2.0390

\begin{abstract}
As a result of lack of information about the thermal, physical and engineering properties of okra gown in Nigeria some of these properties were studied in order to contribute to the database for properties related to grading, handling, packaging, transportation, cleaning, processing, storage and other futuristic processing units. The study showed that the thermal conductivity, specific heat capacity, latent heat and thermal diffusivity were $0.26 \mathrm{Wm}^{-1} \mathrm{~K}^{-1}, 1.77 \mathrm{KJKg}^{-1} \mathrm{~K}^{-1}$, $16.75 \mathrm{KJKg}^{-1}$ and $0.06 \times 10^{-7} \mathrm{~m}^{2} \mathrm{~s}^{-1}$ respectively. The mean values of length, width, thickness, arithmetic mean diameter, geometric mean diameter, equivalent diameter, surface area, volume, sphericity and coefficient of contact surface of okra seeds were $6.58 \mathrm{~mm}, 4.75 \mathrm{~mm}, 2.37 \mathrm{~mm}, 4.56 \mathrm{~mm}, 4.20 \mathrm{~mm}, 4.33 \mathrm{~mm}, 55.44 \mathrm{~mm}^{2}, 38.80 \mathrm{~mm}^{3}, 63.83 \%$ and $63.97 \%$ respectively. While the aspect ratio, flakiness, 1000 seed mass, bulk density, true density and porosity were $72.19 \%$, $49.89 \%, 47.43 \mathrm{~g}, 0.61,0.62$, and $27.00 \%$ respectively. The study also revealed that the angle of ripose and coefficient of static friction for stainless steel, glass, formica and plywood were $24.51^{\circ}, 0.30,0.34,0.37$ and 0.40 respectively. Stainless steel had the lowest coefficient of static friction and so will be most suitable among the materials tested for the production of okra seeds processing machines.
\end{abstract}

Keywords: Physical; Thermal; Engineering; Properties; Okra seed; Equipment; Handling; processing.

\section{Introduction}

Okra (Abelmoschus esculentus (L.) Moench) belongs to the family of Malvaceae. It originates from Ethiopia around Nile River [1] but nowadays, it is widely cultivated in tropics, subtropics, and temperate regions for its immature seed pods which are consumed as a vegetable [2]. The whole okra plant is edible and has various food, non-food and medical applications but the seed is the nutritionally richest part of the okra [3]. Okra is an annual, warm season crop that provides a rich source of industrial oil and protein [4]. Medicinal plants are the gift of nature to humans and animals to have disease-free healthy life and Okra is among the traditional plants having rich nutritional value and proved to have many therapeutic uses [5]. Okra is a new type of healthy vegetable and belongs to the homology of medicine and food in traditional Chinese medicine [6]. According to these researchers, okra is rich in both nutrients and active ingredients such as dietary fiber, vitamins, oils, polysaccharides and polyphenols, which makes it to have antioxidant, antiinflammatory, hypoglycemic, hypolipidemic and other functions.

Okra, which is currently grown mainly as a vegetable crop, has potential for cultivation as an essential oilseed crop due to high amount of oil content (20\%-40\%) in the seed [7], which consists of linoleic acid a polyunsaturated fatty acid essential for human nutrition of up to $47.4 \%$ [8]. The major fatty acids found in okra are about $42 \%$ linoleic, $34 \%$

\footnotetext{
${ }^{*}$ Corresponding author: Abdulkareem Adamu Obomeghei

Department of Food Technology, University of Ibadan, Ibadan, Oyo State, Nigeria.

Copyright (C) 2022 Author(s) retain the copyright of this article. This article is published under the terms of the Creative Commons Attribution Liscense 4.0.
} 
palmitic, and $18 \%$ oleic [9]. The majority of protein and fat are concentrated in the nucleus of the seed, while the fiber are found in the pulp and crusts [10]

Okra seed is an underexploited, underutilized, readily available and cheap crop. Agricultural crops have unique thermal, physical and engineering properties which vary between seeds, nuts, grains and fruits. These properties are important for the design of machines and equipment required for harvesting, packing, cleaning, grading, transportation, storage and processing. Thermal, physical and engineering properties are useful in heat processing, cooling (either by means of air or water), amount of energy needed for specified amount of food material etc. The chemical composition of food materials affects its thermal properties such as specific heat capacity, thermal conductivity, latent heat as well as thermal diffusivity. Several studies have been carried out on okra plant including the seeds: Chemical composition and the antioxidative properties of Nigerian Okra Seed (Abelmoschus esculentus Moench) Flour [3]; Okra: A potential future bioenergy crop in Iran [4]; Okra and its various applications in Drug Delivery, Food Technology , Health Care and Pharmacological Aspects - A Review [5]; Okra seed and seedless pod: Comparative study of their phenolics and carbohydrate fractions and their impact on bread-making [11]; Nutritive Composition and Physicochemical Properties and Oil Contents of Okra (Abelmoschus esculentus L.) Seed in Middle Awash, Ethiopia. [1]; Abelmoschus esculentus(L.): Bioactive Components' Beneficial Properties-Focused on Antidiabetic Role-For Sustainable Health Applications [12]; Preparation, amino acid composition, and in Vitro antioxidant activity of okra seed meal protein hydrolysates [13]; Physicochemical, functional, pasting and sensory properties of wheat flour biscuit incorporated with Okra powder [14]; Okra in Food Field: Nutritional Value, Health Benefits and Effects of Processing Methods on Quality [6]; Extraction of Iraqi Okra Seeds Oil and Study of its Properties During Different Periods [10]; Rheological and physic-chemical characteristics of okra (Abelmoschus esculentus) seed protein-stabilized oil-in-water emulsion as affected by heat and/ or ionic treatment [15]; Nutritional composition and vitamin E of three Iraqi okra (Abelmoschus esculentus L.) seed oil [10]. Thermal, physical and engineering properties of the okra seeds grown in Nigeria which are essential in handling, processing, transportation, packaging, and storage are still lacking. The objective of this study therefore was to determine thermal, physical and engineering properties of dried samples of okra (Abelmoschus esculentus (L.) Moench) seeds produced in Nigeria.

\section{Material and methods}

\subsection{Materials}

Matured and dried okra seeds were purchased from a local dealer at Uchi market, Auchi, Edo State, Nigeria.

\subsection{Methods}

Proximate Composition: The proximate analyses of the seeds were conducted in accordance with the methods described in AOAC [16].

\subsection{Determination of thermal properties}

\subsubsection{Thermal conductivity}

The thermal conductivity $(\mathrm{K})$ of food materials is related to the composition of the material and was estimated using the method described by Sweat [17] as

$\mathrm{K}=0.25 \mathrm{mc}+0.155 \mathrm{mp}+0.16 \mathrm{mf}+0.135 \mathrm{ma}+0.58 \mathrm{~mm}$.

Where, $\mathrm{mc}=$ mass of carbohydrate, $\mathrm{mp}=$ mass of protein, $\mathrm{mf}=$ mass of fat, $\mathrm{ma}=$ mass of ash and $\mathrm{mm}=$ mass of moisture present in the food material.

\subsubsection{Specific heat capacity}

The specific heat capacity of the roots were estimated using the method of Miles et al.[18] as

$\mathrm{Cp}=\operatorname{mwcw}+\operatorname{mscs}(\mathrm{KJ} \operatorname{Kg}-1 \mathrm{~K}-1)$

Where, $\mathrm{cp}=$ specific heat capacity, $\mathrm{mw}=$ mass fraction of water, $\mathrm{cw}=$ specific heat capacity of water $(4.18 \mathrm{KJ} \mathrm{Kg}-1 \mathrm{k}-1)$, $\mathrm{ms}=$ mass fraction of solids, and $\mathrm{cs}=$ specific heat capacity of solids $(1.46 \mathrm{KJ} \mathrm{Kg}-1 \mathrm{~K}-1)$. 


\subsubsection{Latent heat of fussion}

The method of Lamb [19] was used to estimate the latent heat of fussion as

$\mathrm{L}=335 \mathrm{mw}(\mathrm{KJ} \mathrm{Kg}-1)$.

Where, $\mathrm{mw}=$ mass fraction of water.

\subsubsection{Thermal diffusivity}

The thermal diffusivity was estimated as described by Lewis [20] as

$\alpha=\mathrm{K} / \rho \mathrm{Cp}$

where $\alpha=$ thermal diffusivity, $K=$ thermal conductivity, $\rho=$ density, $\mathrm{cp}=$ specific heat capacity.

\subsection{Determination of Physical Properties}

\subsubsection{Seed size}

Twenty (100) seeds were selected at random and the size, in terms of the major diameter (L), intermediate diameter (W) and minor diameter (T) of the seeds were measured using a vernier caliper (Kennedy Tools) reading to $0.01 \mathrm{~mm}$. Determination was replicated thirty times. The average diameter was estimated by using the arithmetic mean and geometric means of the three axial dimensions. The arithmetic mean diameter, Da, equivalent diameter, De and geometric mean diameter, Dg in mm of seeds were estimated using the methods of Galedar, et al., [21]; Mohsenin [22]; and Bahnasawy [23] respectively as

$\mathrm{D}_{\mathrm{a}}=\frac{(L+W+T)}{3}$

$\mathrm{D}_{\mathrm{g}}=(\mathrm{LWT})^{1 / 3}$

$\mathrm{De}_{\mathrm{e}}=\left[\mathrm{L} \frac{(W+T) 2}{4}\right]^{1 / 3}$

Where Da is the arithmetic mean diameter $(\mathrm{mm}), \mathrm{Dg}$ is the geometric mean diameter (mm), De is the equivalent diameter $(\mathrm{mm}), \mathrm{L}$ is the length $(\mathrm{mm}), \mathrm{W}$ is the width $(\mathrm{mm})$, and $\mathrm{T}$ is the thickness $(\mathrm{mm})$.

\subsubsection{Sphericity}

The sphericity ( $\mathrm{Sp}$ ) defined as the ratio of the surface area of the sphere having the same volume as that of the seed to the surface area of the seed, was estimated by the method of Mohsenin [24] as

$$
\mathrm{S}_{\mathrm{p}}=\frac{(L W T) 1 / 3}{L}
$$

\subsubsection{Surface area}

The surface area (S) was estimated using the formula

$$
\mathrm{S}=\pi \mathrm{Dg}^{2}
$$

\subsubsection{Coefficient of contact surface}

The coefficient of contact surface (C.C.S) was calculated according to the method of Abd Alla et al. [25] as

C.C.S. $=\frac{A f-A t}{A f} \times 100$

Where;

Af: Flat area surface $=\frac{\pi}{4}(L W)$ 
At: Transverse area surface $=\frac{\pi}{4}(W T)$

\subsubsection{Aspect ratio}

The aspect ratio ( $\left.R_{a}\right)$ was estimated using the method of Omobouwajo, et al. [26].

$$
\mathrm{R}_{\mathrm{a}}=\left[\frac{W}{L}\right] 100
$$

Where $\mathrm{R}_{\mathrm{a}}=$ aspect ratio, $\mathrm{W}=$ width, $\mathrm{L}=$ Length

Flakiness ratio (Rf) was determined by the method of Ebrahimzadeh et al. [27] as:

$$
\text { (Rf) }=\frac{T}{W}
$$

Where $\mathrm{T}=$ Thicknes, $\mathrm{W}=$ width

\subsubsection{0 seed mass}

The mass of 1000 seeds were determined by using an electronic balance to an accuracy of $0.001 \mathrm{~g}$. The measurement was replicated 5 times for 1000 seeds selected at random [24].

\subsubsection{Unit volume}

The unit volume of 100 individual seed was estimated from the values of length (L), width (W) and thickness (T) using the method of Mohsenin [22] as

$\mathrm{V}=\frac{\pi}{6}(\mathrm{LWT})$

\subsection{Gravimetric properties}

\subsubsection{True density}

The true density of the seed was determined by the toluene displacement technique. Toluene was used instead of water because it is not easily absorbed by agricultural produce. The volume of toluene displaced was found by immersing a weighed quantity of tiger nuts in toluene [28].

$$
\rho_{t}=m / v
$$

Where $m$ is the mass of the seed in $\mathrm{kg}$ and $\mathrm{v}$ is the volume of the seed in $\mathrm{m}^{3}$

\subsubsection{Bulk density}

The average bulk density of the okra seeds was determined by packing weighed seeds into $250 \mathrm{ml}$ measuring cylinder as described by Heidarbeigi et al. [29]. The packed seeds were gently tapped to allow them to settle. The volume of the measuring cylinder occupied by the seeds was recorded. The bulk density was calculated in $\mathrm{g} / \mathrm{ml}$ using the formula;

$$
\text { Bulk density }(\mathrm{Pb})=\frac{\text { weight of materials packed }}{\text { bulk volume }}
$$

\subsubsection{Porosity}

Porosity (E) was computed as a percentage of the true and bulk densities using the equation below as described by Varnamkhasti et al. [30] as

\subsection{Engineering Properties}

\subsubsection{Angle of repose}

The dynamic angle of repose (emptying angle) was determined using the method of Amin et al. [31] and Sessiz et al. [32] as adopted by Idowu and Owolarafe [33]. A regular cylinder of dimensions 100mm diameter and 150mm height 
was used in the determination of the angle of repose. The cylinder was placed on the surface and filled with the sample and then raised gentling until it forms a cone of seeds. This was replicated 10 times. The angle of repose was then calculated using the equation below as

$\Theta=\tan ^{-1}(2 H / D)$

Where $\theta=$ Angle of repose, $\mathrm{H}=$ Height of the pile, $\mathrm{D}=$ Diameter of the pile

\subsubsection{Coefficient of static friction}

The static coefficient of friction $(\mu)$ was determined for each of the following structurally materials namely formica, plywood, stainless steel, and glass according to the method by Orhevba et al. [34]. A four-sided Formica with dimensions of $150 \mathrm{~m} \times 100 \mathrm{~mm} \times 40 \mathrm{~mm}$ opened at both the top and bottom was filled with tiger nuts after placing it on an adjustable tilting surface. The structural surface with the box on its top was gradually raised until the box just started to slide down. The angle of inclination was read from a graduated scale and the coefficient of friction taken as the tangent of the angle. The procedure was repeated for the other structural materials.

$\mu=\tan \beta$

where $\mu=$ coefficient of static friction for the structural material, $\beta=$ angle of inclination

$\beta=\tan ^{-1}$

i.e. Vertical height of inclined plane/ base length of the platform

\subsection{Statistical analysis}

The data obtained were statistically analyzed using Analysis of Variance (ANOVA) with the use of Statistical Package for Social Sciences (SPSS) version 23. The means were compared and separated using Duncan's Multiple Range Test (DMRT) and LSD at $\mathrm{p} \leq 0.05$.

\section{Results and discussion}

\subsection{Proximate composition}

The results of the proximate analysis of the dried and grind okra seeds and flour are presented in Table 1 . The protein, fat and ash contents obtained in this study for the dried seeds are lower than the value $28.21 \pm 1.55 \%, 22.62 \pm 1.48 \%$, $5.21 \pm 1.09 \%$ reported by Çăglayan et al. [35] respectively for dried and grind Turkish okra seed. The fiber content of $17.28 \pm 0.94 \%$ reported for Turkish okra seed was lower than the value obtained in this study. Abdel-Nabaey and AbouTor [36] reported values of $10.16 \pm 0.08 \%, 24.32 \pm 0.45 \%, 15.20 \pm 0.18 \%, 4.00 \pm 0.11 \%$ and $25.55 \pm 0.21 \%$ for moisture, protein, fat, ash, and fiber respectively for Egyptian okra seed flour. The differences in the reported values could be attributed to different agronomic practices. Zerihun et al. [1] reported values which are similar to the ones obtained in this study. They reported $21.27 \pm 0.02,15.74 \pm 0.13,4.70 \pm 0.10,4.72 \pm 0.01$ and $53.57 \pm 0.22 \%$ for protein, fat, ash, moisture and carbohydrate respectively for dried and grind okra seed grown in Addis Ababa. The protein, fat, fiber and ash reported by Georgia de Sousa et al. [37] for okra seed flour were 22.14 $\pm 1.04,14.01 \pm 0.50,30.81 \pm 0.31$ and $4.01 \pm 0.21 \%$ respectively. These values are slightly lower than the reported values obtained in this experiment.

Table 1 Proximate composition of dried okra seeds g/ 100g

\begin{tabular}{|c|c|c|}
\hline Parameter & Dried seed & Flour \\
\hline Protein & $18.07 \pm 0.17^{\mathrm{a}}$ & $18.39 \pm 0.16^{\mathrm{a}}$ \\
\hline Fat & $14.00 \pm 1.00^{\mathrm{a}}$ & $13.11 \pm 0.60^{\mathrm{a}}$ \\
\hline Fiber & $31.00 \pm 0.10^{\mathrm{a}}$ & $27.00 \pm 1.00^{\mathrm{b}}$ \\
\hline Ash & $4.13 \pm 0.12^{\mathrm{a}}$ & $3.33 \pm 0.58^{\mathrm{a}}$ \\
\hline Moisture & $5.00 \pm 0.00^{\mathrm{a}}$ & $5.00 \pm 0.10^{\mathrm{a}}$ \\
\hline Carbohydrate & $39.93 \pm 0.11^{\mathrm{a}}$ & $33.17 \pm 0.27^{b}$ \\
\hline
\end{tabular}




\subsection{Thermal properties}

The results of the thermal properties of okra seeds are presented in Table 2. The values obtained showed that there were no significant difference between the seeds and the flour $(\mathrm{P} \leq 0.05)$ for thermal conductivity, latent heat and thermal diffusivity. But the results showed that significant difference exist between the seeds and four in terms of specific heat capacity. The specific heat capacity for the seeds was found to be significantly higher than that of the flour. The means that more energy will be needed to cook the seed than the flour.

Table 2 Thermal properties of dried okra seeds

\begin{tabular}{|l|c|c|}
\hline \multicolumn{1}{|c|}{ Parameter } & Dried seeds & Flour \\
\hline Thermal conductivity $\mathrm{Wm}^{-1} \mathrm{~K}^{-1}$ & $0.26 \pm 0.01^{\mathrm{a}}$ & $0.23 \pm 0.01^{\mathrm{a}}$ \\
\hline Specific heat capacity $\mathrm{KJ} \mathrm{Kg}^{-1} \mathrm{~K}^{-1}$ & $1.77 \pm 0.12^{\mathrm{a}}$ & $1.60 \pm 0.11^{\mathrm{b}}$ \\
\hline Latent heat of fussion $\mathrm{KJ} \mathrm{Kg}^{-1}$ & $16.75 \pm 0.15^{\mathrm{a}}$ & $16.75 \pm 0.01^{\mathrm{a}}$ \\
\hline Thermal diffusivity $\times 10^{-7} \mathrm{~m}^{2} \mathrm{~s}^{-1}$ & $0.06 \pm 0.01^{\mathrm{b}}$ & $0.22 \pm 0.01^{\mathrm{a}}$ \\
\hline
\end{tabular}

\subsection{Physical properties}

The results of the physical properties for okra seeds are presented in Table 3. The value of major diameter obtained in this study was found to be lower than $8.10 \mathrm{~mm}$ reported by Davis [38] for okra produced in Yenagoa, Nigeria but higher than $5.50 \mathrm{~mm}$ reported by Badgujar et al. [39] for Punjab okra, 5.73mm reported by Vinod et al. [40] for Indian okra and $5.85 \mathrm{~mm}$ reported by Darwish and Moussa [41] for okra cultivated in Egypt. The intermediate diameter was found to be slightly lower than $4.83 \mathrm{~mm}$ reported by Vinod et al. [40] but higher than $2.70 \mathrm{~mm}$ reported by Davis [38], $4.60 \mathrm{~mm}$ reported by Badgujar et al. [39] and $4.40 \mathrm{~mm}$ reported by Darwish and Moussa [41]. The minor diameter obtained in this study is lower than $2.50 \mathrm{~mm}$ reported by Davis [38], $4.10 \mathrm{~mm}$ reported by Badgujar et al. [39], $4.49 \mathrm{~mm}$ reported by Vinod et al. [40] and $4.01 \mathrm{~mm}$ reported by Darwish and Moussa [41]. Abdel-Nabey and Abou-Tor [36] reported 5.35 $\mathrm{mm}, 4.88 \mathrm{~mm}$ and $4.24 \mathrm{~mm}$ for major, intermediate and minor diameters for Egyptian okra seed flour. The arithmetic mean diameter reported in this experiment was found to be similar to $4.40 \mathrm{~mm}$ and $4.75 \mathrm{~mm}$ obtained by Davis [38] and Darwish and Moussa [41] respectively. The geometric mean diameter reported in this study is higher than $3.80 \mathrm{~mm}$ obtained by Davis [38] but similar to $4.70 \mathrm{~mm}, 4.98 \mathrm{~mm}$ and $4.68 \mathrm{~mm}$ obtained by Badgujar et al. [39], Vinod et al. [40] and Darwish and Moussa [41] respectively. The value for equivalent diameter reported in this research work was found to be similar to the value 4.00 obtained by Davis [38]. The okra seeds used in this work are more spherical in shape than those used by Davis [38] with 47.52\% spericity but less spherical than those of Badgujar et al. [39], Vinod et al. [40] and Darwish and Moussa [41] with values for sphericity of $85 \%, 87.90 \%$ and $80.43 \%$ respectively.

Table 3 Physical properties of dried okra seeds

\begin{tabular}{|l|c|}
\hline \multicolumn{1}{|c|}{ Parameter } & Value \\
\hline Major diameter $(\mathrm{L}) \mathrm{mm}$ & $6.58 \pm 0.15$ \\
\hline Intermediate diameter $(\mathrm{W}) \mathrm{mm}$ & $4.75 \pm 0.16$ \\
\hline Minor diameter $(\mathrm{T}) \mathrm{mm}$ & $2.37 \pm 0.15$ \\
\hline Arithmetic Mean Diameter $\left(\mathrm{D}_{\mathrm{a}}\right)$ & $4.56 \pm 0.12$ \\
\hline Geometric Mean Diameter $\left(\mathrm{D}_{\mathrm{g}}\right)$ & $4.20 \pm 0.13$ \\
\hline Equivalent Diameter $\left(\mathrm{D}_{\mathrm{e}}\right)$ & $4.33 \pm 0.13$ \\
\hline Sphericity \% & $63.83 \pm 15.72$ \\
\hline Surface area $\times 10^{4} \mathrm{~mm}^{2}$ & $55.44 \pm 0.36$ \\
Coefficient of contact surface & $63.97 \pm 1.10$ \\
\hline Aspect ratio $\%$ & $72.19 \pm 14.39$ \\
\hline Flakiness ratio & $49.89 \pm 0.27$ \\
\hline
\end{tabular}




\begin{tabular}{|l|l|}
\hline 1000 seed mass $(\mathrm{g})$ & $47.43 \pm 3.67$ \\
\hline Unit volume $\left(\mathrm{mm}^{3}\right)$ & $38.80 \pm 0.04$ \\
\hline
\end{tabular}

\subsubsection{Values are means of ten determinations}

The surface area of okra seeds reported in this study was $55.44 \mathrm{~mm}^{2}$. This value is higher than 4.50 obtained by Davis [38] but lower than $69.77 \mathrm{~mm}^{2}$ obtained by Darwish and Moussa [41]. The coefficient of contact surface obtained in this work was found to be far higher than the value 30.77 reported by Darwish and Moussa [41]. The value for aspect ratio obtained in this study was far higher than the $32.92 \%$ reported by Davis [38]. This implies that the seeds used in this experiment will roll while the seeds used by Davis [38] will slide rather than roll. This information is required for the design of hoppers. The 1000 grain mean mass obtained in this work was lower than 93.54g reported by Davis [38], 55.16 reported by Vinod et al. [40] and 61.27g reported by Darwish and Moussa [41].

\subsection{Gravimetric properties}

The results of the gravimetric properties are presented in Table 4. The value for the bulk density obtained in this study is slightly lower than the value $0.63 \pm 0.03 \mathrm{kgm}^{-3}$ reported by Darwish and Moussa [41] for okra seed grown in Cairo but higher than the values $0.51 \mathrm{kgm}^{-3}$ reported by Vinod et al. [40] for okra seeds grown in India, $0.59 \mathrm{kgm}^{-3} \mathrm{reported} \mathrm{by}$ Badgujar et al. [39] for okra seeds cultivated in Punjab and $0.46 \mathrm{kgm}^{-3}$ reported by Davis [38] for okra seed grown in Yenagoa, Nigeria. The true density obtained in the work is lower than $0.90 \mathrm{kgm}^{-3}$ reported by Darwish and Moussa [41] for Egyptian okra seeds, $1.07 \mathrm{kgm}^{-3}$ obtained by Vinod et al. [40] for okra seed grown in India and $0.74 \mathrm{kgm}^{-3} \mathrm{reported}$ by Davis [38] for okra seed cultivated in Yenagoa, Nigeria. The differences observed in these values could be due to varietal difference and agronomical practices. Density is also affected by moisture content of the seeds [39].

Table 4 Gravimetric properties of dried okra seeds

\begin{tabular}{|l|c|}
\hline \multicolumn{1}{|c|}{ Parameter } & Value \\
\hline True density $\left(\mathrm{kgm}^{-3}\right)$ & $0.62 \pm 0.01$ \\
\hline Bulk density $\left(\mathrm{kgm}^{-3}\right)$ & $0.61 \pm 0.01$ \\
\hline Porosity \% & $27.00 \pm 0.94$ \\
\hline
\end{tabular}

\subsubsection{Values are means of ten determinations}

The porosity of okra seeds obtained in this experiment was observed to be lower than 33.81\% reported by Darwish and Moussa (2020), 37.27\% reported by Davis (2020), and 49.10\% reported by Vinod et al. (2018).

\subsection{Engineering properties}

The engineering properties of dried okra seeds are presented in Table 5. The angle of ripose obtained in this study is similar to 24.24 reported by Badgujar et al. [39] for Punjab okra seeds but lower than 28.930 obtained by Davis [38] for okra seed cultivated in Yenagoa, Nigeria, 28.65 reported by Vinod et al. [40] for okra seed of India origin and 29.15 reported by Darwish and Moussa [41] for Egyptian okra seeds.

Table 5 Engineering properties of dried okra seeds

\begin{tabular}{|l|l|}
\hline Parameter & Value \\
\hline Angle of repose $\left({ }^{\circ}\right)$ & $24.51 \pm 1.15$ \\
\hline \multicolumn{2}{|c|}{ Coefficient of static friction } \\
\hline Formica & $0.37 \pm 0.03$ \\
\hline Glass & $0.34 \pm 0.03$ \\
\hline Stainless steel & $0.30 \pm 0.04$ \\
\hline Plywood & $0.40 \pm 0.07$ \\
\hline \multicolumn{2}{|c|}{ Values are means of ten determinations }
\end{tabular}


The coefficient of static friction for stainless steel obtained in this experiment is similar to the values 0.33 reported by Davis [38] for okra seed grown in Yenagoa, Nigeria and 0.27 reported by Darwish and Moussa [41] for Egyptian okra seeds. Also the value for plywood obtained in this study is in agreement with the value 0.40 reported by Darwish and Moussa [41] for Egyptian okra and 0.45 reported by Davis [38]. The value for plywood was found to be higher than all other materials while stainless steel was lowest. This is because stainless steel has a smoother and polished surface follow closely by glass, formica and lastly by plywood. Angle of ripose and coefficient of static friction are required in designing equipment for solid flow and storage structures.

\section{Conclusion}

This study on okra seeds at 5.00\% moisture content revealed the following conclusions

The thermal conductivity, specific heat capacity, latent heat of fusion, and thermal diffusivity were $0.26 \mathrm{Wm}^{-1} \mathrm{~K}^{-1}$, $1.77 \mathrm{KJKg}^{-1} \mathrm{~K}^{-1}, 16.75 \mathrm{KJKg}^{-1}$ and $0.06 \times 10^{-7} \mathrm{~m}^{2} \mathrm{~s}^{-1}$.

The mean length, width, and thickness were $6.58 \mathrm{~mm}, 4.75 \mathrm{~mm}$ and $2.37 \mathrm{~mm}$. The sphericity, aspect ratio, and flakiness were $63.83 \%, 72.19 \%$ and $49.89 \%$.

The volume, bulk density, true density and porosity were $38.80 \mathrm{~mm}^{3}, 0.61 \mathrm{Kgm}^{-3}, 0.62 \mathrm{Kgm}^{-3}$ and $27.00 \%$.

The angle of ripose and coefficient of static friction for stainless steel, glass, formica and plywood were $24.51^{\circ}, 0.30$, $0.34,0.37$ and 0.40 .

\section{Compliance with ethical standards}

\section{Acknowledgments}

The Authors gracefully thank Unuigbe Odion Michael and Malik Ogu of the Department of Agricultural Engineering Technology, Auchi polytechnic, Auchi for laboratory assistance.

\section{Disclosure of conflict of interest}

The authors declare that they do not have any conflict of interest.

\section{Statement of ethical approval}

This research does not involve the use of animal or human subject.

\section{References}

[1] Zerihun M, Berhe H, Mulu M, Agrgahgn Z, Demelie M. Nutritive Composition and Physicochemical Properties and Oil Contents of Okra (Abelmoschus esculentus L.) Seed in Middle Awash, Ethiopia. J Food Process Technol. 2020; 11(10): 848 .

[2] Rizwan HF, Irshad M, He BZ, Liu S, Lu XX, Sun YT, Qiu DL. Role of reduced nitrogen for induction of embryogenic callus induction and regeneration of plantlets in Abelmoschus escu-lentus L. South African Journal of Botany. 2020; 130: 300- 307.

[3] Adelakun OE, Oyelade OJ, Ade-Omowaye BIO, Adeyemi IA, Van de Venter M, Koekemoer TC. Chemical composition and the antioxidative properties of Nigerian Okra Seed (Abelmoschus esculentus Moench) Flour. Food and Chemical Toxicology. 2009; 47(6): 1123 -1126.

[4] Seyed AM, Majid A, Barat G, Ebrahim F. Okra: A potential future bioenergy crop in Iran. Renewable and Sustainable Energy Reviews. 2018; 93: 517-524.

[5] Das S, Nandi G, Ghosh K. Okra and its various applications in Drug Delivery, Food Technology, Health Care and Pharmacological Aspects - A Review. Journal of Pharmaceutical Sciences and Research. 2019; $11(6): 2139$ - 2147.

[6] Ying Liu, Jingyi Qi, Junyun Luo, Wen Qin, Qingying Luo, Qing Zhang, DingtaoWu, Derong Lin, Suqing Li, Hongmin Dong, Daiwen Chen \& Hong Chen: Okra in Food Field: Nutritional Value, Health Benefits and Effects of Processing Methods on Quality, Food Reviews International. 2019. 
[7] Aminu Y, Maryam MG, Kabiru SA. Hormonal response of gibberellin (ga3), grafting and seasonal variations on growth and yield parameters on Okra (Abelmoschus esculentus). Am Int J Biol Life Sci. 2019; 1: 33 - 39.

[8] Habtamu Fekadu Gemede, Negussie Ratta, Gulelat Desse Haki\& Ashagrie Z. Woldegiorgis Fekadu Beyene. Nutritional Quality and Health Benefits of Okra (Abelmoschus esculentus): A Review. Global Journal of Medical Research (K). 2015; 14(5): 28 - 37.

[9] Savello PA, Martins F, Hill W. Nutrition composition of okra seed meals. Jour-nal of Agricultural and Food Chemistry. 1980; 28: 1163 - 1166.

[10] AL-Kanani EAS, AL-Hilifi SAH, AL- Kareem AH. The nutritional composition and vitamin E of three Iraqi okra (Abelmoschus esculentus L.) seeds oil. Earth Environ. Sci. 2019; 388: 012058.

[11] Kang X, Mengmeng G, Laura R, Joana P, Mario MM. Okra seed and seedless pod: Comparative study of their phenolics and carbohydrate fractions and their impact on bread-making. Food Chemistry. 2020; $317: 126387$.

[12] Alessandra D, Massimo L, Ettore N, Eliana BS, Daliu P, Antonello S. Abelmoschus esculentus(L.): Bioactive Components'Beneficial Properties-Focused on AntidiabeticRole-For Sustainable Health Applications. Molecules. 2019; 24: 38.

[13] Hong LY, JiaNi Y, JiaJia Z, Qu L, Min S, Yao JJ. Preparation, amino acid composition, and in Vitro antioxidant activity of okra seed meal protein hydrolysates Food Science and Nutrition. Food Sci Nutr. 2021; 00: 1-12.

[14] Akoja SS, Coker OJ. Physicochemical, functional, pasting and sensory properties of wheat flour biscuit incorporated with Okra powder. International Journal of Food Science. 2018; 3(5): 64 - 70.

[15] Makeri MU, Bagirei SY, Buba W, Dam AG, Kassum A. Reological and Physico-chemical characteristics of okra (Abelmoschus esculentus) seed protein stabilized oil-in-water emulsion as affected by heat and/ or ionic treatment (s). J Chem. Soc. Nigeria. 2019; 44(6): 1121 - 1131.

[16] AOAC. Methods of Analysis of Association of Official Analytical Chemists, 18th Edition. Washington DC, USA. 2010.

[17] Sweat VE. Thermal properties of foods. In: Rao MA, Rizui SSH (Ed.), Engineering properties of foods. Marcel Dekker Inc. New York. 1986; 49.

[18] Miles CA, Van beek G, Veerkamp CH. Calculation of thermophysical properties of foods. In: Jowitt R (Ed.), Phyical properties of foods. Applied Science, London. 1983.

[19] Lamb J. Experimental study. Influence of water on the physical properties of foods. Chem. Ind. $1976 ; 24: 1046$.

[20] Lewis MJ. Physical properties of foods and food processing systems. Ellis Horwood Ltd, Chichester, England. $1987 ; 223$.

[21] Galedar MN, Jafari A, Tabatabaeefa A. Some physical properties of wild pistachio nut and kernel as a function of moisture content. Journal of Physics and Environmental and Agricultural Sciences. 2008; 22: 117-124.

[22] Mohsenin NN. Physical Properties of Plant and Animal Materials. Gordon and Breach Press, New York, USA. 1986.

[23] Bahnasawy AH. Some physical and mechanical properties of garlic. Int. Journal of Food Engineering. 2007; 3(6): $1-18$.

[24] Mohsenin NN. Physical Properties of Plant and Animal Materials: structure, physical characteristics and Mechanical properties. 1st Edn. Gordon and Breach Science Publishers. New York, USA. 1978.

[25] Abd Alla HE, Radwan SM, El Hanafy EH. Effect of some physical properties of rice grains on milling quality. Misr J. Agric. Eng. 1995; 12(1): 143-155.

[26] Omobuwajo TO, Sanni LA, Olajide JO. Physicalproperties of ackee apple seeds. J. Food Eng. 2000; 45: 43-48.

[27] Ebrahimzadeh H, Mirzabe AH, Lotfi M, Azizinia S. Gamma radiation effects on physical properties of squash seeds. Agriculture engineering international: CIGR journal. 2013; 15(1): 131 -138.

[28] Singh KK, Goswami TK. Physical properties of Cumin seed. J. Agric. Eng. Res. 1996; 64: 93 - 98.

[29] Heidarbeigi K, Ahmadi H, Kheiralipour K, Tabatabaeefar A. Some physical and mechanical properties of Khinjuk. Pakistan Journal of Nutrition. 2013; 8(1): 74-77.

[30] Varnamkhasti MG, Mobli V, Jafri A, Rafiee S, Heidarysohanabadi M, Kheiralpour K. Some engineering properties of paddy (varsazandegi). International Journal of Agriculture and Biology. 2007; 9(5): 763-766. 
[31] Amin MN, Hossain MA, Roy KC. Effect of moisture content on some physical properties of lentil seeds. Journal of Food Engineering. 2004; 65: 83-87.

[32] Sessiz A, Esgici R, Krizi K. Moisture-Dependent Physical Properties of Caper (capparis ssp.) fruit. Journal of Food Engineering. 2007; 79: $1426-1431$.

[33] Idowu DO, Owolarafe OK. Effect of Moisture content and loading orientation on some strength properties relevant in the Design of Snake Gourd (Trichosanthes cucumerina L.) seed Handling device. Int. CIGRE journal. 2015; $17(4): 337-345$.

[34] Orhevba BA, Idah PA, Adebayo SE, Nwankwo CC. Determination of some engineering properties of dika nut (Irvinga gabonensis) at two moisture content level as relevant to its processing. International Journal Engineering Research and Applications. 2013; 3(2): 182 -188.

[35] Çağlayan A, Alev AB, Ecem MA, Duygu G. Chemical composition of Turkish okra seeds (Hibiscus esculentaL.) and the total phenolic content of okra seeds flour. Anadolu University Journal of Science and Technology, Applied Sciences and Engineering. 2016; 17(5): 766-774.

[36] Abdel-Nabey AA, Abou - Tor E - SM. Chemical Composition of Okra Seeds and Some Physico-Chemical Characteristics of Extracted Oil. Alexandra Journal of Food Sci. Tech. 2014; 11(1): 11 - 19.

[37] Georgia de Sousa FS, Vinicius de Morais G, Anderson dos Reis A, Manoel BD, Raul R, Antonio G, Darlene CP, Carlos AG, Jose de Carvalho M, Tatiane SG. Specroscopic and Thermooxidative Analysis of Organic Okra oil and seeds from Abelmoschus esculentus. The Scientific World Journal. 2012; 12.

[38] Davis RM. Some physical properties of okra fruits and seeds. International Journal of Emerging Engineering Research and Technology. 2020; 8(1): 23 - 29.

[39] Badgujar CM, Dhingra HS, Manes GS, Khurana R, Gautam A. Engineering properties of okra (Abelmoschus esculentus) seed. Agric. Research Journal. 2018; 55(4): 722 - 728.

[40] Vinod K, Vijaya R, Mukesh J, Anil K, Sushil K, Naresh. A study on physical properties of okra seed: Abelmoschus esculentus (L.). Advances in Research. 2018; 14(3): 1 - 7.

[41] Darwish EA, Moussa AM. Some phesoengineering properties of okra seeds determination. Journal of Sciences and Agricultural Engineering. 2020; 11(12): 853 - 856. 